\title{
Methamphetamine Causes Alterations in the MAP Kinase-Related Pathways in the Brains of Mice that Display Increased Aggressiveness
}

\author{
Boris P Sokolov*,' and Jean L Cadet' \\ 'Molecular Neuropsychiatry Branch, National Institute on Drug Abuse, NIH, DHHS, Baltimore, MD, USA
}

Aggressive behaviors have been reported in patients who suffer from some psychiatric disorders, and are common in methamphetamine (METH) abusers. Herein, we report that multiple (but not single) injections of METH significantly increased aggressiveness in male CD-I mice. This increase in aggressiveness was not secondary to METH-induced hyperactivity. Analysis of protein expression using antibody microarrays and Western blotting revealed differential changes in MAP kinase-related pathways after multiple and single METH injections. There were statistically significant $(p<0.05)$ decreases in MEKI, Erk2p, GSK3 $\alpha, 14-3-3 e$, and MEK7 in the striata of mice after multiple injections of METH. MEKI was significantly decreased also after a single injection of METH, but to a much lesser degree than after multiple injections of METH. In the frontal cortex, there was a statistically significant decrease in GSK3 $\alpha$ after multiple (but not single) injections of METH. These findings suggest that alterations in MAP kinase-related pathways in the prefronto-striatal circuitries might be involved in the manifestation of aggressive behaviors in mice.

Neuropsychopharmacology (2006) 31, 956-966. doi:I0.1038/sj.npp. I 30089I; published online 28 September 2005

Keywords: proteomics; violence; drug abuse; psychiatric disorders

\section{INTRODUCTION}

Violence and aggressive behaviors are important public health problems because of their medical and criminal consequences (Dahlberg, 1998; Golding, 1996; Lederhendler, 2003; Prothrow-Stith, 1995). These issues are compounded by the fact that increased aggressiveness is often observed in patients who suffer from bipolar disorder, major depressive disorder, and antisocial personality disorders (Posternak and Zimmerman, 2002; Swann et al, 2004). Aggressive behaviors are also quite common among abusers of methamphetamine (METH, speed) (Carey and Mandel, 1968; Ellinwood, 1971; Hawks et al, 1969; Miczek and Tidey, 1989; Szuster, 1990). As aggressive behaviors and social interactions can also be influenced by METH in rodents, cats, and non-human primates (Crowley, 1972; Maeda et al, 1985; Miczek and O'Donnell, 1978; Shintomi, 1975; Sokolov et al, 2004), understanding of neuronal adaptations that might be associated with METH-induced aggressiveness in animals should provide a window toward

\footnotetext{
* Correspondence: Dr BP Sokolov, Molecular Neuropsychiatry Branch, National Institute on Drug Abuse, $\mathrm{NIH}, \mathrm{DHHS}, 5500$ Nathan Shock Drive, Baltimore, MD 21224, USA, Tel: + I 410550 I582×391, Fax: + I 410550 2742, E-mail: Bsokolov@intra.nida.nih.gov

Received 21 February 2005; revised 7 June 2005; accepted 5 August 2005

Online publication: 5 August 2005 at http://www.acnp.org/citations/ Npp080505050 I |4/default.pdf
}

identifying some of the neurobiological substrates that subsume these behaviors.

Complex psychosocial behaviors, including neuropsychiatric disorders, such as bipolar and major depressive disorders, that often involve increased aggressiveness (Posternak and Zimmerman, 2002; Swann et al, 2004), are thought to be secondary to dysfunctions in prefrontostriatal circuitries (Strakowski et al, 2005). Dysfunctions in prefronto-striatal circuits might also subsume psychostimulant abuse, which is frequently associated with violent behaviors (Gold et al, 1989; London et al, 2004; Schultz, 2002; Sekine et al, 2001). These clinical observations suggest that the prefronto-striatal system is involved in aggressive behaviors. There is extensive literature regarding the association between frontal lobe injury and aggressiveness (Brower and Price, 2001). For example, a study of 279 Vietnam veterans, who had suffered penetrating head injuries, indicated that patients with frontal ventromedial lesions had significantly higher Aggression/Violence Scale scores than controls and patients with lesions in other brain areas (Grafman et al, 1996). Comparative neuropsychology has also provided evidence for a role for the striatum in certain forms of aggression. Examining human subjects with focal lesions affecting the ventral striatum demonstrated a disproportionate impairment in recognizing human signals of aggression, suggesting the role of the striatum in coding signals of aggression (Calder et al, 2004). Abnormalities in striatal dopamine re-uptake sites in 
habitually violent alcoholic offenders has been reported (Kuikka et al, 1998). Moreover, enhanced defensive aggressiveness, excessive alcohol intake, and impulsive behavior were found in rats following extensive lesions of the ventral striatum and the septal area (Johansson and Hansen, 2000). Furthermore, chemical lesions of the nucleus accumbens septi have been reported to influence apomorphine-induced aggression in rats (Pucilowski and Valzelli, 1986). These observations suggest that prefronto-striatal circuits may be involved in the regulation of aggressive behaviors. As a first step towards testing this idea, we sought to discriminate patterns of protein expression in the brains of mice that exhibited aggressive behaviors after chronic treatment with METH. Herein, we report that repeated injections of METH over a period of 8 weeks caused marked alterations in the expression of proteins involved in MAP kinaserelated pathways in the striata and frontal cortex of aggressive mice.

\section{METHODS}

All animal use procedures were according to the National Institutes of Health Guide for the Care and Use of Laboratory Animals and were approved by the Animal Care and Use Committee of NIDA IRP. All efforts were made to use the minimal possible number of animals to address the questions raised by the current study.

Male CD-1 mice (9-11 weeks old) were obtained from The Jackson Laboratory (Bar Harbor, ME). Mice were randomly assigned to the METH/METH (chronic METH), Sal/METH (acute METH), or Sal/Sal (control) groups. Before being given the injections, mice were habituated to their environment for 1 week. Mice were housed in groups of four or in a cage $\left(27 \times 16 \times 12 \mathrm{~cm}^{3}\right)$ with free access to food and water. Mice were single housed, starting the 6 th week when they were 15-17 weeks old. They were maintained on a $12 \mathrm{~h}$ light/ dark cycle (lights on at $0700 \mathrm{~h}$ ) at $21 \pm 2{ }^{\circ} \mathrm{C}$.

The chronic METH regimen was designed to bear some degree of similarity with clinical patterns of METH abuse, which can vary significantly, but usually include gradual increases of drug intake at early stages and occasional interruptions of drug use after binges (Cadet et al, 2003; Kramer et al, 1967; Yen et al, 2005). METH/METH mice received intraperitoneal injections of $\mathrm{METH}$ in $0.5 \mathrm{ml}$ of saline at 0800 and $1400 \mathrm{~h}$ according to the following schedule of escalating METH doses: during the first week on day 1 , the mice were injected with $1 \mathrm{mg} / \mathrm{kg}(0800 \mathrm{~h})$ and $2 \mathrm{mg} / \mathrm{kg}(1400 \mathrm{~h})$ of METH; on day 2, they were injected with $3 \mathrm{mg} / \mathrm{kg}(0800 \mathrm{~h})$ and $4 \mathrm{mg} / \mathrm{kg}(1400 \mathrm{~h})$; and on day 3, they received $5 \mathrm{mg} / \mathrm{kg}(0800 \mathrm{~h})$ and $6 \mathrm{mg} / \mathrm{kg}(1400 \mathrm{~h})$ of METH. After these escalating METH injections, mice did not get the drug for 2 days. During the second, third, and sixth-eight weeks, they received two injections of METH $(6 \mathrm{mg} / \mathrm{kg})$ at 0800 and $1400 \mathrm{~h}$ for 5 days; they received no injections on the last 2 days of the week. Moreover, the animals did not get any injections on the fourth and fifth weeks.

Control (Sal/Sal) mice received repeated injections of $0.5 \mathrm{ml}$ of saline on a similar schedule as the $\mathrm{METH} / \mathrm{METH}$ animals. Sal/METH mice received saline in a fashion similar to the Sal/Sal mice, except for the last injection, which was one of METH (6 mg/kg). This approach is different from the administration of single dose large or multiple moderate doses of METH which cause neurotoxic damage to the rodent brain (Cadet et al, 2003).

\section{Assessment of Locomotor Activity}

Cages with mice were transported to the testing room 45-60 min before the start of the test session to minimize the possible effects of stress associated with the transfer. In order to examine locomotor activity immediately after METH challenge, mice chronically treated with saline or METH were placed in an activity monitor cage (Med. Associates, Inc., East Fairfield, VT) in the morning, $19 \mathrm{~h}$ after the last injection, and locomotor activity was recorded for $15 \mathrm{~min}$ as $\mathrm{cm} / \mathrm{min}$ traveled. At this time point, mice were challenged with $6 \mathrm{mg} / \mathrm{kg} \mathrm{METH}$ and recording locomotor activity was continued for another $30 \mathrm{~min}$. The total observation time was $45 \mathrm{~min}$.

Locomotor activity at 4 and $20 \mathrm{~h}$ after METH challenge was tested in other groups of mice. To test locomotor activity at 4 or $20 \mathrm{~h}$ after injection, each animal from each treatment group was taken from its home cage, injected with either SAL (Sal/Sal group) or $6 \mathrm{mg} / \mathrm{kg}$ METH (METH/ $\mathrm{METH}$ and Sal/METH groups), and returned to its home cage. At 4 or $20 \mathrm{~h}$ point after challenge with $\mathrm{METH}$, the cage was placed into an activity monitor. Mice were allowed to habituate to the activity monitor for $15 \mathrm{~min}$ and then activity was recorded for $15 \mathrm{~min}$.

\section{Assessment of Aggressiveness}

Aggressiveness was examined as the latency time before the first bite attack using the 'resident-intruder' paradigm (Miczek and O'Donnell, 1978). Tested mice (residents) were single-housed for 3 weeks before tests and received no treatments. Intruder mice were housed in groups of four. Intruder mice were of the same age and from the same shipment as the tested mice. In order to avoid injury, intruder mice were removed immediately after attack. Bedding in cages was changed once a week. Tests for aggressiveness were performed on days 6 or 7 after changing the bedding. In order to avoid confounds caused by stress related to moving, tests were performed in the same room where the mice were housed. Each mouse was tested only once and each intruder was used in only one test. Latency before the bite attack was measured as the time between the placement of the intruder in the resident cage and the first bite attack. The latency for mice that did not initiate a bite attack was assumed to be $900 \mathrm{~s}$, which corresponded to the total time of observation.

\section{Antibody Microarray Analysis}

The antibody microarrays (BD Clontech AB Microarray 380, BD, Biosciences, Palo Alto, CA) used in the current study were composed of 378 distinct monoclonal antibodies printed at high density on a glass microscope slide. Sal/Sal and METH/METH mice pairs were assigned for the analysis randomly. The Ab Mircoarray 380 contains antibodies with specificities for proteins related to signal transduction, oncogene products, cell cycle regulation, cell structure, apoptosis, and neurobiology among others. 
About $95 \%$ of the antibodies are directed at intracellular proteins, while approximately $5 \%$ are cytokines and receptors. In all, $95 \%$ of the antibodies were raised against human proteins. Whenever possible, antibodies that also recognize the specific mouse and rat proteins where chosen. The specific details on the cross-species reactivities for each antibody can be found on the antibodies datasheet found on the BD Biosciences Pharmingen website (http://www. clontech.com/clontech/products/families/abarray/index.shtml). Total protein for microarray analysis was extracted from $75-100 \mathrm{mg}$ of striatum (including the caudate and nucleus accumbens) or frontal cortex by homogenizing in Extraction/Labeling Buffer provided by the manufacturer of microarrays. Extracted proteins were then labeled by covalent attachment of fluorophores Cy3 or Cy5. After protein labeling, unbound dye was removed by gel exclusion chromatography using PD-10 Desalting Columns (Amersham Biosciences). The protocol was designed to effectively control for variations in labeling efficiency. Specifically, the METH/METH and SAL/SAL samples were each split into two equal portions. Each portion was then labeled with either $\mathrm{Cy} 5$ or $\mathrm{Cy} 3$ to produce four samples: METH/METH-Cy3, METH/METH-Cy5, SAL/SAL-Cy3, and SAL/SAL-Cy5. In labeling proteins, each of the dye solutions was split into equal portions so that both samples react with identical dye stocks. The labeled samples were combined to produce a mixture of $\mathrm{Cy} 5$ - and Cy3-labeled proteins. METH/METH-Cy3 was combined with SAL/SAL-Cy5 (mixture \#1), while METH/METH-Cy5 was combined with SAL/ SAL-Cy3 (mixture \#2). After thorough mixing, an aliquot from each mix ( $50 \mu \mathrm{g}$ of total protein) was incubated with a separate array in separate chambers, washed, dried, and scanned using GenePix 4000B Axon scanner (Axon Instruments, Union City, CA). Сy3/Cy5 ratio for each antigen captured on microarray was determined from the ratio of absorbance at 552 and $650 \mathrm{~nm}$, respectively. Internally normalized ratio (INR) for each antigen was then calculated as root square of the ratio between $\mathrm{Cy} 5 / \mathrm{Cy} 3$ ratio in the mixture $\# 2$ and $\mathrm{Cy} 5 / \mathrm{Cy} 3$ ratio in the mixture $\# 1$.

\section{Kinetworks ${ }^{\mathrm{TM}}$ KPKS 1.0 Protein Kinase Screen}

Brain tissue was homogenized on ice in the following buffer: $20 \mathrm{mM}$ MOPS, $\mathrm{pH}$ 7.0, $2 \mathrm{mM}$ EGTA, $5 \mathrm{mM}$ EDTA, and 0.5\% Triton X100. To inhibit protein-serine phosphatases, the buffer also contained $30 \mathrm{mM}$ sodium fluoride, $40 \mathrm{mM} \beta$ glycerophosphate, and $10 \mathrm{mM}$ sodium pyrophosphate. To inhibit protein-tyrosine phosphatases, the buffer contained $2 \mathrm{mM}$ sodium orthovanadate. To inhibit proteases, the buffer contained $1 \mathrm{mM}$ phenylmethylsulfonylfluoride, $3 \mathrm{mM}$ benzamide, $5 \mu \mathrm{M}$ pepstatin $\mathrm{A}$, and $10 \mu \mathrm{M}$ leupeptin. Tissue homogenates were diluted to a protein concentration of $1.0 \mathrm{mg} / \mathrm{ml}$ in SDS-PAGE sample buffer. The final composition of the sample buffer in the sample was $31.25 \mathrm{mM}$ Tris- $\mathrm{HCl}(\mathrm{pH} 6.8), 1 \%$ SDS (w/v), 12.5\% glycerol (v/v), and $0.02 \%$ bromophenol blue (w/v). The sample was boiled for $4 \mathrm{~min}$ at $100^{\circ} \mathrm{C}$ and stored at $-20^{\circ} \mathrm{C}$. Kinetworks ${ }^{\mathrm{TM}}$ KPKS 1.0 high-throughput Western blotting analysis of the expression of 75 different protein kinases was performed by Kinexus Bioinformatics Corp. (Canada), with $800 \mu \mathrm{g}$ of brain tissue lysate protein. Quantification of the immunoreactive bands on the Kinetwork blots with ECL detection was performed with a Bio-Rad FluroS Max Imager and BioRad Quantity One software.

\section{Western Blotting}

Proteins for Western blotting were prepared as described for the Kinetworks analysis (see above). Proteins (10-15 $\mu \mathrm{g} /$ well) were separated on a 7.5 or $10 \%$ SDS-polyacrylamide gel and transferred onto nitrocellulose (Bio-Rad) membranes. The MEK1/2, phospho-Mek1/2 (Ser-217/Ser-221) antibody (rabbit polyclonal IgG, affinity purified) was obtained from Cell Signaling Technology (New England Biolabs). Anti-rabbit secondary antibody, antibiotin antibody conjugated to horseradish peroxidase, and biotinylated protein marker were also obtained from Cell Signaling Technology. Chemiluminescent detection was performed using Phototope-HRP Western Detection Kit (Cell Signaling Technology). For quantification of band density, films were analyzed using BioImaging Systems and Lab Works Imaging and Analysis densitometric software (UVP, Inc., Upland, CA).

\section{Data Analysis}

Differences between groups were examined using one-way ANOVA, followed by Dunnett's treatment $v s$ control post hoc test (two-tailed). Dunnett's post hoc test treats one group (SAL/SAL) as control and compares all other groups against it. The significance of difference in $\mathrm{AB}$ microarray analysis was examined using one-sample $t$-test (two-tailed). Statistical analysis was carried out using SSPS 13.0 for Windows. Data are expressed as means $\pm S E$, with the number of individual experiments presented in the figures and tables.

\section{RESULTS}

\section{Effects of Repeated and Single METH Injections on Aggressive Behaviors}

Aggressiveness was measured as time latency before the first bite attack in the resident/intruder test. Time latency before an attack measured at both $15 \mathrm{~min}$ and $20 \mathrm{~h}$ after the METH challenge was significantly shorter in mice chronically treated with METH (METH/METH group) than in mice treated with saline (SAL/SAL group). By contrast, time latency in mice that received a single injection of METH (SAL/METH group) was not different from controls (SAL/ SAL group) (Figure 1).

\section{Effects of the METH Challenge on Locomotor Activity}

The METH injection caused an increase in locomotor activity in mice chronically treated with METH and mice chronically pretreated with saline, with the METH-pretreated mice showing significantly greater changes (Figure 2a). Locomotor activity remained increased $4 \mathrm{~h}$ after the METH challenge in mice chronically treated with METH $(p=0.003)$, but not in saline-treated mice (SAL/ METH group) (Figure 2b). No significant changes in locomotion were found when the mice were tested $20 \mathrm{~h}$ after the METH challenge (Figure 2c). These observations are in contrast to those observed in the test of aggressive 


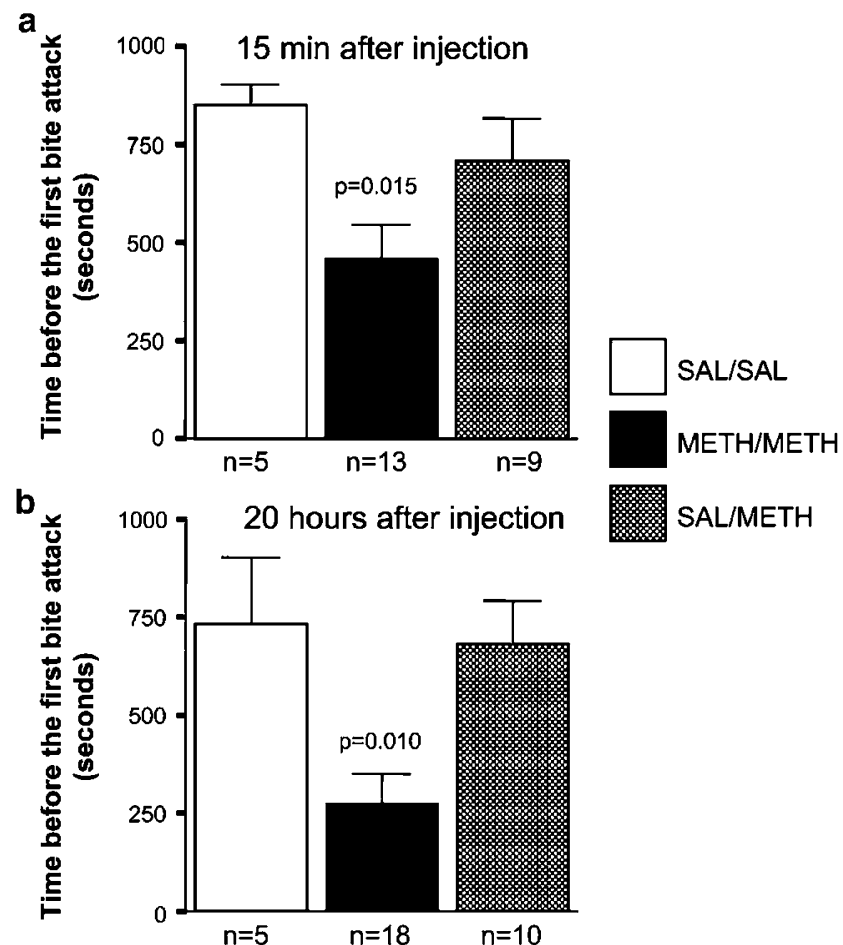

Figure I Chronic treatment with METH increases aggressiveness in mice measured 15 min or $20 \mathrm{~h}$ after the last injection. Latency time before the first bite attack on the intruder was recorded in resident-intruder paradigm. Latency time was measured 15 min (a) or $20 \mathrm{~h}$ (b) after injection of METH (METH/METH and SAL/METH groups) or saline (SAL/SAL group). Note that the time before the bite attack was significantly shorter in mice chronically treated with METH both at the 15-min and 20-h time points. ANOVA revealed significant differences among the groups (ANOVA, $F=4.000, d f=2,24, p=0.032$ and $F=6.26, d f=2,32$, $p=0.005$ at 15 -min and 20-h time points, respectively). Post hoc analysis revealed significant difference between the METH/METH and SAL/SAL groups ( $p=0.015$ and 0.01 at I5-min and 20-h time points, respectively).

behaviors (see Figure 1). Qualitative observations revealed stereotypic behaviors in mice chronically treated with METH, but not in mice that received a single injection of METH. The most common stereotypic behaviors were running in circles, constant grooming, or poking heads into the bedding. These behaviors typically began several minutes after the METH challenge and continued for several hours. No apparent stereotypy was evident $20 \mathrm{~h}$ after METH challenge. Stereotypy apparently did not preclude measurements of locomotor activity in our experiments, since, as illustrated in Figure 2a, despite stereotypy, mice treated with METH chronically showed greater hyperlocomotion after METH challenge than did saline-treated mice challenged with same dose of METH.

\section{Antibody Microarray Analysis}

Mice chronically injected with METH (METH/METH mice) were compared to mice chronically injected with saline (SAL/SAL mice). Tissues from the striatum and frontal cortex were collected $4 \mathrm{~h}$ after the last injection. The 4 -h time point lies within the interval of time when mice chronically treated with METH display increased aggressiveness. This time point was selected because $4 \mathrm{~h}$ after injection only mice chronically treated with METH exhibited hyperlocomotion, while mice that received a single injection of METH did not. Thus, METH-induced behavioral changes at this time point were likely to be due to neuroadaptative changes rather than due to the acute effects of METH. The average difference in protein abundance between METH/METH and SAL/SAL mice measured using $\mathrm{AB}$ microarrays from five independent experiments was less than $9 \%$ for all but two proteins, which indicated 13 and $15 \%$ differences, respectively (data not shown). For the purpose of further evaluation, we define proteins as possibly affected if they replicated greater than $5 \%$ increases or decreases in 4 or 5 out of 5 independent experiments comparing METH/METH mice with SAL/SAL mice (Table 1). By these criteria, there were seven downregulated and one upregulated proteins after chronic METH treatment, including Erk2 and 14-3-3e (Table 1); these results suggested possible alterations in MAP kinase-related pathways in mice chronically treated with METH.

\section{Analysis of MAP Kinase-Related Pathways Using Kinetworks Protein Kinase Screen}

Striatum. Three other groups of mice were injected using either METH/METH $(n=11)$, SAL/METH $(n=9)$, or SAL/ SAL $(n=9)$ treatment regimens. Tissues were collected $4 \mathrm{~h}$ after the last injection. Protein samples from two or four animals were pooled for each analysis to reduce individual variability and to reduce the cost of the analysis. Four pools for the METH/METH and SAL/SAL groups and three pools for the SAL/METH group were prepared. According to Kinexus recommendations, fold changes in immunoreactivity greater than 1.25 in a single experiment may be considered as evidence of altered abundance of a protein. In this study, we chose to apply more stringent criteria for changes. Changes were considered to be robust if the fold changes from repeated independent experiments (four experiments for the METH/METH mice and three experiments for the SAL/MET mice) were greater than 1.5. Kinetworks analysis confirmed lower abundance of Erk2 (both total and phosphorylated Erk2) in the striatum of mice chronically treated with METH (Table 2). Importantly, two different antibodies were used to measure Erk 2 in the Kinetworks analysis, and both revealed similar magnitudes of changes (Table 2). Erk2 reduction revealed by Kinetworks screen (Table 2) was greater than reduction revealed using antibody microarrays (Table 1), indicating, possibly, greater sensitivity of Kinetworks screen compared to antibody microarrays. It is important to note, however, that different specificities of antibodies and different groups of animals were used in $\mathrm{AB}$ microarrays and Kinetworks screen. Measurements of other MEK1/2/Erk1,2 pathwayrelated protein kinases revealed decreases in Erk1 and several upstream protein kinases, including Raf1(72), MOS, MEK1, as well as in several downstream protein kinases, including RSK2, GSK $3 \alpha$, and GSK $3 \beta$ (Table 2 ). The level of the upstream regulator of the Erk1/2 pathway, protein kinase A (PKA), was decreased, whereas levels of the PKC $\alpha$ and $\mathrm{PKC} \zeta$ subunits of protein kinase $\mathrm{C}$ (PKC) were increased in the striata of METH/METH mice. Decreases in MEK1, Erk2p, GSK3 $\alpha$, and MEK7 in METH/METH mice 

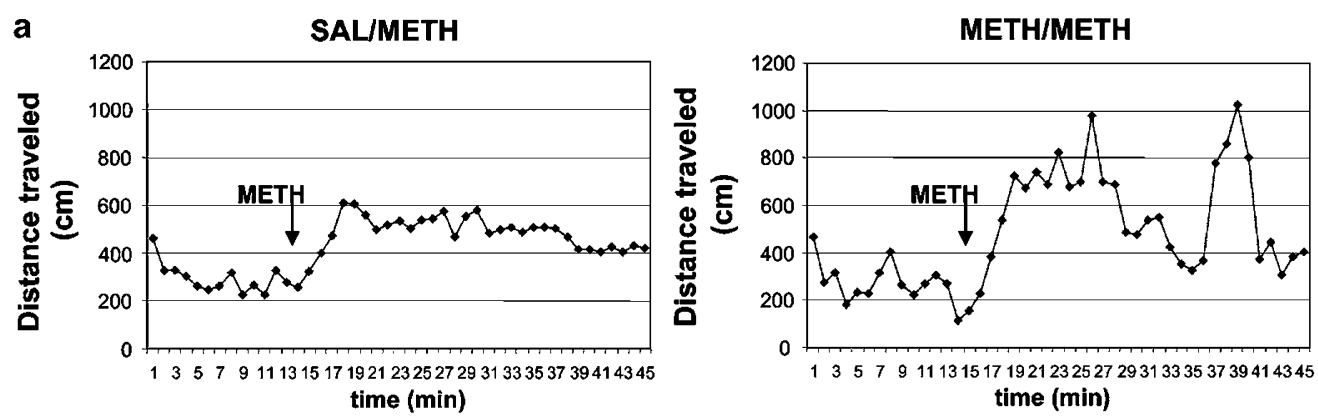

b 4 hours after injection
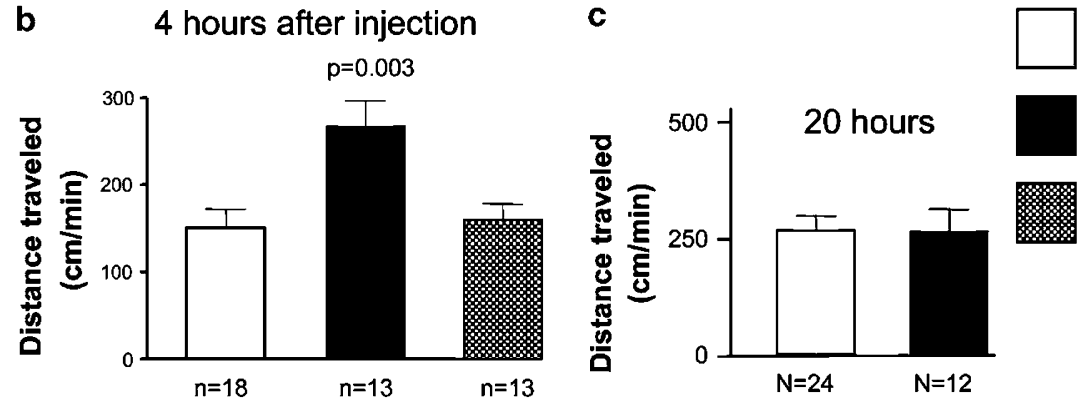

SAL/SAL

METH/METH

SAL/METH

Figure 2 Chronic treatment with METH sensitizes mice to the locomotion-stimulating effect of METH. Effect of METH on locomotor activity in mice. (a) Effect of METH at the I5-min time point after challenge with METH. Mice chronically treated with saline (left panel) or with METH (right panel) were placed in locomotor activity monitored $19 \mathrm{~h}$ after the last injection, and the distance traveled was recorded for $15 \mathrm{~min}$. Mice then received an injection of METH $(6 \mathrm{mg} / \mathrm{kg})$ and locomotor activity was recorded for another $30 \mathrm{~min}$. Data are the means for 12 mice in each of the groups and are given in 1 -min blocks. Arrow indicates the time of injection of METH. (b) Effect of METH challenge $4 \mathrm{~h}$ after injection. Separate groups of mice received $6 \mathrm{mg} / \mathrm{kg} \mathrm{METH}$ (SAL METH and METH/METH groups) or saline (SAL/SAL group). After $4 \mathrm{~h}$, mice were placed in an activity monitor. Mice were allowed to habituate to the activity monitor for $15 \mathrm{~min}$ and locomotor activity was recorded for $15 \mathrm{~min}$. Data are shown as average distance per minute traveled during the 15 min of observation. Locomotor activity measured $4 \mathrm{~h}$ after injection was increased in mice that were chronically treated with METH (METH/METH mice), but was not increased in mice that received a single dose of METH (SAL/METH mice) compared with SALSAL mice (ANOVA, F = 7.08I, df $=2,4 \mathrm{I}, p=0.002 ;$ post hoc tests showed significant ( $p=0.003$ ) differences between SAL/SAL and METH/METH mice). (c) Locomotor activity measured $20 \mathrm{~h}$ after the last injection was not increased in METH/METH mice compared with SAL/SAL mice. Data are mean \pm SEM.

Table I Antibody Microarray (Proteins Changed in the Striatum of Mice Chronically Treated with METH ${ }^{\mathrm{a}}$ )

Ratio of protein level in METH/METH mouse to SAL/SAL mouse

Pairs of mice

\begin{tabular}{lccccc}
\cline { 2 - 6 } Protein name & $\mathbf{I}$ & $\mathbf{2}$ & $\mathbf{3}$ & $\mathbf{4}$ & $\mathbf{5}$ \\
\hline Erk 2 & 0.86 & 0.90 & 0.92 & 1.09 & 0.94 \\
l4-3-3e* & 1.03 & 0.86 & 0.90 & 0.91 & 0.90 \\
p53 & 0.91 & 1.04 & 0.87 & 0.89 & 0.91 \\
p2I (Cip I/NAFI)* & 0.89 & 0.92 & 0.93 & 1.00 & 0.90 \\
Integrin b3 (CD6I)* & 0.95 & 0.99 & 0.87 & 0.94 & 0.90 \\
NFAT-I** & 0.94 & 0.97 & 0.90 & 0.93 & 0.94 \\
NHE-3* & 1.00 & 0.93 & 0.93 & 0.90 & 0.98 \\
Arginase I & 1.10 & 1.07 & 1.11 & 0.96 & 1.06 \\
\hline
\end{tabular}

${ }^{*} p<0.05, * * * 0.01$ one-sample $t$-test (two-sided).

Tissue was collected $4 \mathrm{~h}$ after the last METH or saline injection.

${ }^{a}$ Change greater than $5 \%$ replicated in four out of five METH/METH and

SAL/SAL pairs of mice.

were statistically significant $(p<0.05)$. Of the changes observed after chronic treatment with METH, only Erk1, Erk2, and GSK $\alpha$ showed similar changes in the striata of mice treated with a single injection of METH; however, differences did not reach statistical significance (Table 2).

Frontal cortex. The level of GSK $3 \alpha$ in the frontal cortex was significantly $(p<0.05)$ decreased after chronic treatment, but not after a single injection of METH (Table 3). Other changes in the frontal cortex did not reach statistical significance and included nominal increases in $\mathrm{PKC} \alpha$, $\mathrm{PKC} \zeta$, and $\mathrm{PKC} \delta$ and decrease in $\mathrm{PKC} \mu(120)$ after both repeated and single injections of METH (Table 3). There were also increases in levels of $\mathrm{PKC} \beta 1, \mathrm{PKC} \varepsilon$, and $\mathrm{PKC} \gamma$ in the frontal cortex after repeated injections of $\mathrm{METH}$ (Table 3). Level of Erk1p was decreased after chronic treatment, but not after a single injection of METH (Table 3).

\section{Total and Phosphorylated MEK1 in the Striatum} at 4- and 20-h Time Points after METH Injection

The Kinetworks analysis revealed significant reduction of striatal MEK1 after repeated METH injections, but only modest changes after a single injection (Table 2). As these observations had suggested a role for MEK1 in aggressiveness associated with chronic treatment with METH and because MEK1 plays a central role in the MEK1,2/Erk1,2 pathway, total and phosphorylated MEK1 expression was assessed in the striata from other groups of animals using antibodies different from those used in the Kinetwork analysis. Immunoreactivity was measured $20 \mathrm{~h}$ after METH 
Table 2 Analysis of MAP Kinase-Related Pathways in Striatum Using Kinexus Kinetworks Protein Kinase Screen

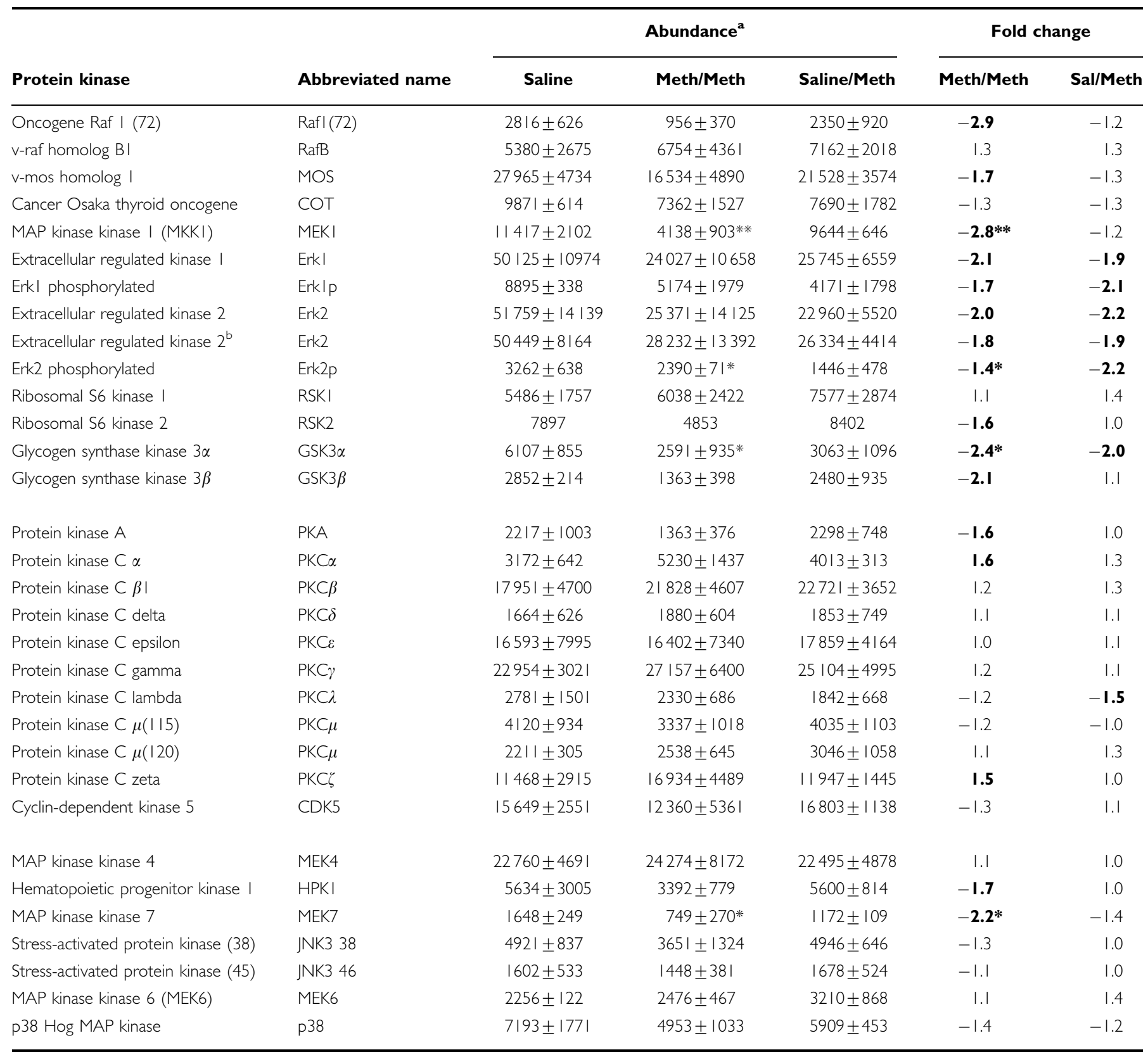

Data were from Western blotting of tissue from I I mice in the METH/METH, nine in SAL/METH, and nine in SALSAL groups. In each of the treatment group tissue was pooled from two or three mice. Four pools of samples were examined for METH/METH, three for SALMETH, and four for SAL/SAL groups.

Bold indicate fold changes greater than I.5.

$* p<0.05 ; * * 0.01$, Dunnet post hoc test, two tailed. Tissue was collected $4 \mathrm{~h}$ after the last METH or saline injection.

a Measured by the area under intensity profile curve. Units are intensity $\times \mathrm{mm}$. Data are means \pm SEM.

${ }^{b}$ Erk2 was measured using two different antibodies.

ANOVA, MEKI: $F=9.16, d f=2,8, p=0.009 ;$ Erk2p: $F=3.46, d f=2,8, p=0.08 ; G S K 3 a: F=5.23, d f=2,8, p=0.035 ; M E K 7: F=5.05, d f=2,8, p=0.039$.

injection when aggressiveness was increased without hyperlocomotion, and also at $4 \mathrm{~h}$ after injection when significant hyperlocomotion was evident in METH/METH but not in SAL/METH mice (Figures 1 and 2).

Consistent with the Kinetworks analysis, levels of total MEK1 measured $4 \mathrm{~h}$ after injection were significantly lower in METH/METH mice compared with SAL/SAL mice (Figure $3 \mathrm{a}$ and $\mathrm{b}$ ). MEK1 remained significantly decreased at $20 \mathrm{~h}$ after the METH injection in METH/METH mice. At that time, a smaller reduction of MEK1 was found in mice that received a single dose of METH (Figure 3a and b). Analysis of the phosphorylated form of MEK1 in mice chronically treated with METH revealed significant reduction at $4 \mathrm{~h}$ after the last METH injection (Figure $3 \mathrm{a}$ and $\mathrm{b}$ ). Significantly greater decreases in phosphorylated MEK1 were observed in the METH/METH group at $20 \mathrm{~h}$ after injection with METH (Figure $3 \mathrm{a}$ and $\mathrm{b}$ ). Levels of phosphorylated MEK1 were also decreased $4 \mathrm{~h}$ after a single 
Table 3 Analysis of MAP Kinase-Related Pathways in Frontal Cortex Using Kinexus Kinetworks Protein Kinase Screen

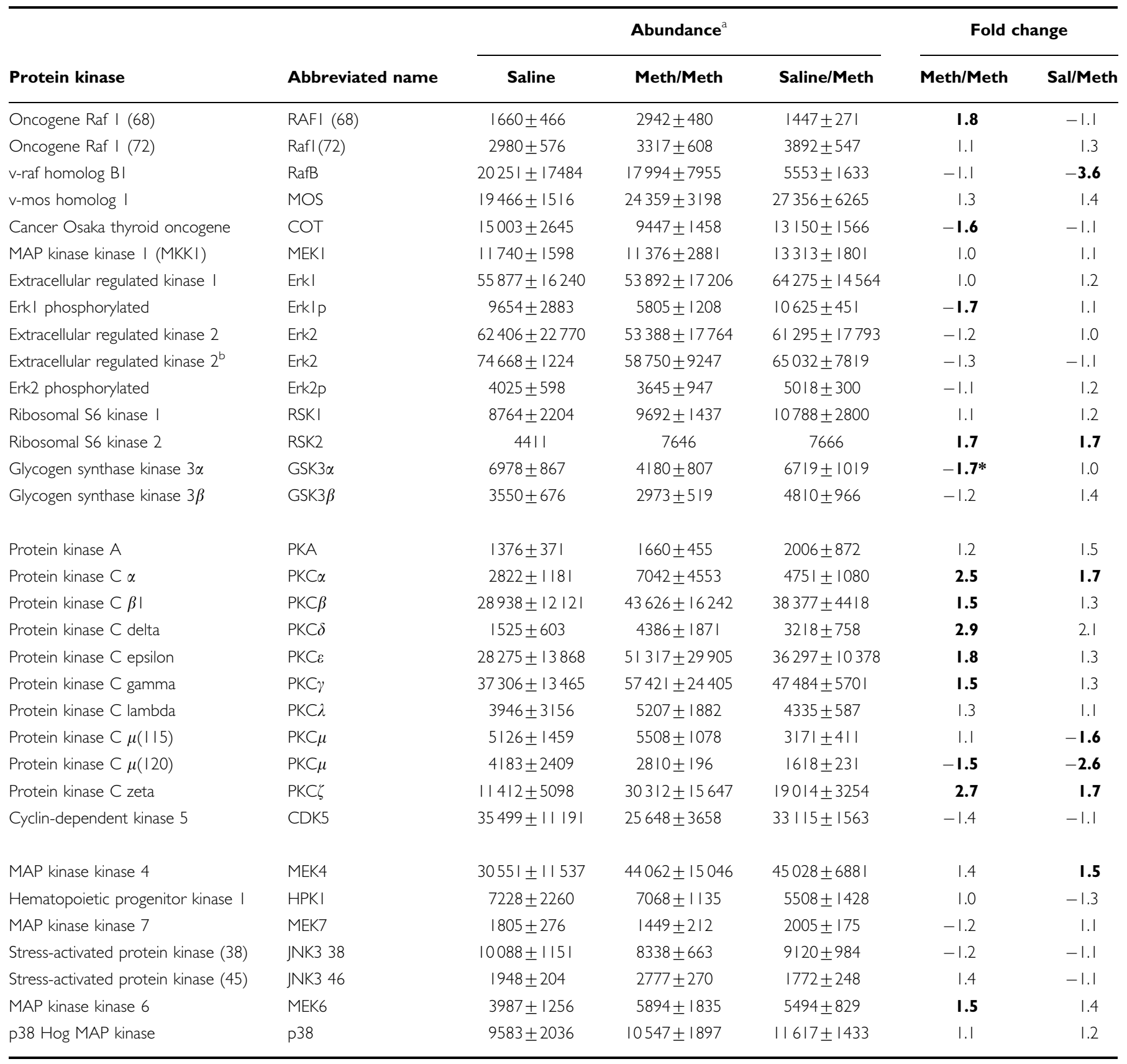

Data were from Western blotting of tissue from I I mice in the METH/METH, nine in SAL/METH, and nine in SAL/SAL groups. In each of the treatment group, tissue was pooled from two or four mice. Three pools of samples were examined for each the METH/METH, SALMETH, and SAL/SAL groups.

a Measured by the area under intensity profile curve. Units are intensity $\times \mathrm{mm}$. Data are means \pm SEM.

berk2 was measured using two different antibodies.

Bold indicate fold changes greater than 1.5.

* $p<0.05$, Dunnet's post hoc test, two tailed. Tissue was collected $4 \mathrm{~h}$ after the last METH or saline injection.

injection of METH. In contrast, no significant changes in phosphorylated MEK1 were observed $20 \mathrm{~h}$ after a single injection of METH.

\section{DISCUSSION}

METH abuse is associated with a high rate of aggressive behaviors, affective instability, and poor impulse control
(Carey and Mandel, 1968; Ellinwood, 1971; Hawks et al, 1969; Szuster, 1990). These observations suggest the possibility that these patients might suffer from dysfunctions within subcortical striato-prefrontal networks that subsume human emotional, cognitive, and social behaviors (Strakowski et al, 2005). In the present study, we found significantly increased aggressiveness in mice chronically treated with METH, observations that were not dependent on gross activation of locomotor activity. Antibody micro- 
a

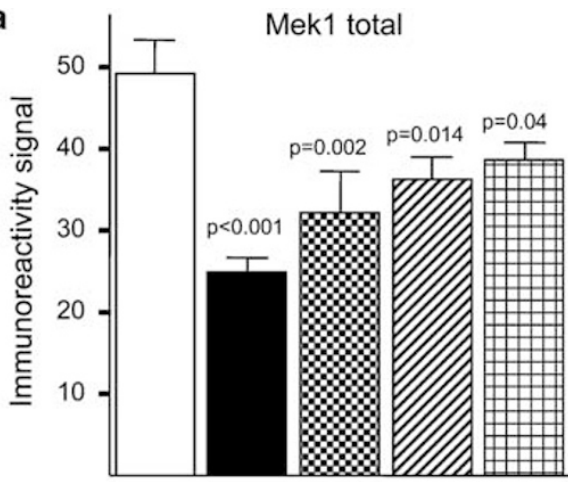

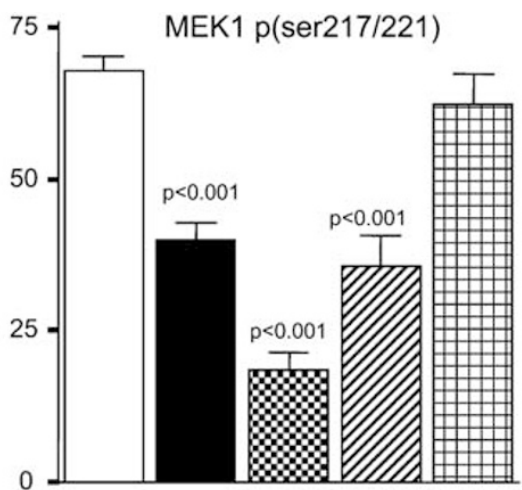

b
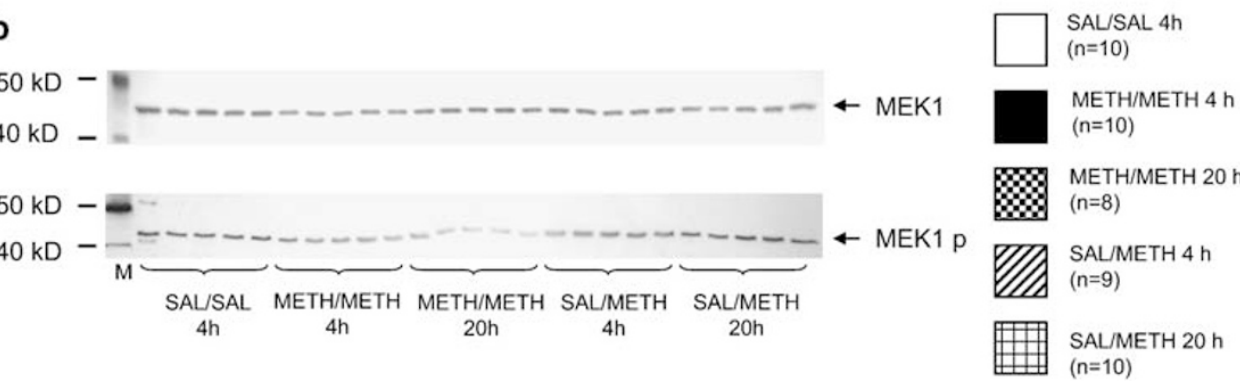

Figure 3 Western blotting analysis of total and phosphorylated forms of MEKI in the striatum from mice 4 or $20 \mathrm{~h}$ after injection. (a) Levels of immunoreactivity. ANOVA revealed significant differences between the treatment groups both for total MEKI $(F=7.832, \mathrm{df}=4,42, p<0.00 \mathrm{I})$ and for phosphorylated MEKI ( $F=26.497, \mathrm{df}=4,42, p<0.00 \mathrm{I})$. P-values above the individual bars indicate significant difference from SAL/SAL revealed in the post hoc test. (b) Representative Western blots.

array analysis revealed decreases in the levels of Erk2 and $14-3-3 e$ in the striata of the mice chronically treated with METH. As protein kinase Erk2 is thought to be the principal component of the classical MAP kinase pathway and because 14-3-3e is an inhibitor and substrate of PKC (Jones et al, 1995), the decreases in these two proteins suggest that repeated METH injections might perturb MAP kinaserelated pathways in the striato-prefrontal circuitries. This idea is supported by Western blotting analyses that also revealed changes in multiple components of MAP kinaserelated pathways in the striatum and frontal cortex of aggressive mice chronically treated with METH. Thus, MAP kinase-related pathways in the prefronto-striatal circuits might be involved in the manifestations of aggressive behaviors induced by repeated injection of METH.

The use of animal models to get insights into human violence and aggressive behaviors is a challenging task because of the complexity and multidimensional nature of these behaviors (Lederhendler, 2003; Miczek et al, 2001). The fact that increased aggressiveness in mice was observed only after long-term treatment with METH suggests that METH-induced aggressiveness in mice might be a valuable model to study aggressiveness associated with METH abuse in humans. This observation is supported by the fact that increased aggressiveness in mice was not dependent on METH-induced hyperlocomotion. These observations suggest that these behavioral changes reflect neuroadaptations in mechanisms involved in the regulation of aggressive behaviors in rodents. Thus, it is not far-fetched to suggest that METH-induced aggressive behaviors, which developed over time, might be secondary to drug-mediated disruptions of inhibitory circuits that might be involved in suppressing aggressive behaviors. One obvious limitation of the current study is that it does not answer fully the question related to how much of the effects seen in the METH/METH group are residual or due to molecular responses to the last METH injection. Future studies using various time intervals after the last injection are needed to clarify this question.

MAP kinases are abundant within neuronal cell bodies and dendrites, where they regulate a variety of functions including neurotransmission and ion channel activities at synapses (Chen et al, 2001; Davis et al, 2000; Sharma et al, 2002). MAP kinase-related pathways, including the classical MEK1,2/Erk1,2 pathway as well as PKC- and PKAdependent cascades, have been implicated in behavioral abnormalities observed in substance abuse and in affective disorders (Chen et al, 1999; Dwivedi et al, 2001; Einat et al, 2003a, b; Freeman et al, 2001a, b; Manji and Chen, 2002; Mizoguchi et al, 2004; Valjent et al, 2000). These ideas are consistent with our observations that changes in MAP kinase-related proteins in the striatum were more abundant after being repeated than after a single injection of METH. For example, statistically significant decreases in Gsk $3 \alpha$, MEK7, and pErk2 were observed only after repeated injections of METH. In addition, MEK1 was dramatically reduced after chronic METH treatment, but only modestly reduced after a single injection of METH, while phosphorylated MEK1 at 20-h time point was significantly reduced only after repeated METH injections. These changes in phosphorylated MEK1 might be secondary to decreased abundance of the upstream protein kinase Raf1. When taken together, these observations are consistent with the idea that alterations observed after chronic METH treat- 
ment are consequent to neuroadaptive mechanisms induced by chronic METH treatment, but not by acute direct affects of METH on neuronal systems.

Our findings that mice that display short attack latency against an intruder after chronic treatment with METH also experience significant changes in MAP kinase-related pathways are consistent with the results of a recent report in which the technique of serial analysis of gene expression (SAGE) was used to measure gene expression in two mice lines genetically selected for short and long attack latency (Feldker et al, 2003). This SAGE analysis revealed that mice with short attack latency showed lower expression of genes encoding components of MAP kinase pathways (Feldker et al, 2003). The concordance of the results obtained using two different approaches, that is, pharmacological (here) and genetic (Feldker et al, 2003), and different techniques (transcripts $v s$ protein abundance) strongly supports the idea that MAP kinase-related pathways may be involved in aggressive behaviors. These suggestions are also consistent with the reported involvement of MAP kinase pathways in the regulation of several neurotransmitter systems (Della Rocca et al, 1999; Greengard, 2001) that have been implicated in the regulation of aggressivity. These include serotonergic (Birger et al, 2003; Davidge et al, 2004; Edwards and Kravitz, 1997; Ferris et al, 1999; Huber et al, 1997; Korte et al, 1996; Manuck et al, 2002; Miczek et al, 2001), dopamine, norepinephrine, GABA, glutamate, acetylcholine, cholecystokinin, substance $\mathrm{P}$, and opioid neurotransmitter systems (Brodkin et al, 2002; Chiavegatto et al, 2001; Olivier et al, 1995; Siegel et al, 1999).

Another line of evidence to support the idea that MAP kinase-related pathways may be involved in aggressive behaviors comes from studies of the mood stabilizers, lithium and valporate. In addition to their use to treat affective disorders, lithium and valporate have been used for the management of aggressive behaviors in various pathological conditions, including mental retardation, brain injury, autism, schizophrenia, attention-deficit/hyperactivity disorder, conduct disorder, and pervasive developmental disorder (Bellus et al, 1996; Glenn et al, 1989; Goetzl et al, 1977; Malone et al, 1994; McDougle et al, 2003; Platt et al, 1981; Schiff et al, 1982; Shader et al, 1974; Sheard, 1975, 1984; Silva et al, 1993; Swann, 2003; Weller et al, 1999; Wroblewski et al, 1997). Lithium has also been reported to block aggressiveness in laboratory animals (Sheard, 1975). The therapeutic effects of lithium and valporate are thought to be related to their regulatory actions on several members of MAP kinase-related pathways (Bhat et al, 2004; Chen et al, 1999; Hao et al, 2004; Manji and Chen, 2002; Manji and Lenox, 1999), similar to those that are affected in mice chronically treated with METH.

In conclusion, the present study identified complex changes in MAP kinase-related pathways in the striatum and frontal cortex of mice that display increased aggressiveness after receiving repeated METH injections. Given the role of these kinase cascades in the regulation of various cortical and striatal neurotransmitter systems that are thought to be involved in the modulation of aggressive behaviors in various animal models, our observations are consistent with the view that these pathways might be involved in the regulation of aggressive behaviors in mice. Further studies are needed to examine how stable over time are behavioral and molecular changes induced by long-term treatment with $\mathrm{METH}$, and to delineate the role of specific protein kinases in specific METH-induced behaviors.

\section{ACKNOWLEDGEMENTS}

This research was supported by the Intramural Research Program of the NIDA, NIH, DHHS. We thank Dr CW Schindler for providing activity monitor and helpful suggestions. We also thank B Ladenheim for his expert help in brain dissections.

\section{REFERENCES}

Bellus SB, Stewart D, Vergo JG, Kost PP, Grace J, Barkstrom SR (1996). The use of lithium in the treatment of aggressive behaviours with two brain-injured individuals in a state psychiatric hospital. Brain Injury 10: 849-860.

Bhat RV, Budd Haeberlein SL, Avila J (2004). Glycogen synthase kinase 3: a drug target for CNS therapies. J Neurochem 89: 1313-1317.

Birger M, Swartz M, Cohen D, Alesh Y, Grishpan C, Kotelr M (2003). Aggression: the testosterone-serotonin link. Israel Med Assoc J 5: 653-658.

Brodkin ES, Goforth SA, Keene AH, Fossella JA, Silver LM (2002). Identification of quantitative trait loci that affect aggressive behavior in mice. J Neurosci 22: 1165-1170.

Brower MC, Price BH (2001). Neuropsychiatry of frontal lobe dysfunction in violent and criminal behaviour: a critical review. J Neurol Neurosurg Psychiatry 71: 720-726.

Cadet JL, Jayanthi S, Deng X (2003). Speed kills: cellular and molecular bases of methamphetamine-induced nerve terminal degeneration and neuronal apoptosis. FASEB J 17: 1775-1788.

Calder AJ, Keane J, Lawrence AD, Manes F (2004). Impaired recognition of anger following damage to the ventral striatum. Brain 127: 1958-1969.

Carey JT, Mandel J (1968). A San Francisco Bay Area 'speed' scene. J Health Soc Behav 9: 164-174.

Chen G, Huang LD, Jiang YM, Manji HK (1999). The moodstabilizing agent valproate inhibits the activity of glycogen synthase kinase-3. J Neurochem 72: 1327-1330.

Chen Z, Gibson TB, Robinson F, Silvestro L, Pearson G, Xu B et al (2001). MAP kinases. Chem Rev 101: 2449-2476.

Chiavegatto S, Dawson VL, Mamounas LA, Koliatsos VE, Dawson TM, Nelson RJ (2001). Brain serotonin dysfunction accounts for aggression in male mice lacking neuronal nitric oxide synthase. Proc Natl Acad Sci USA 98: 1277-1281.

Crowley TJ (1972). Dose-dependent facilitation or suppression of rat fighting by methamphetamine, phenobarbital, or imipramine. Psychopharmacologia 27: 213-222.

Dahlberg LL (1998). Youth violence in the United States. Major trends, risk factors, and prevention approaches. Am J Prev Med 14: 259-272.

Davidge KM, Atkinson L, Douglas L, Lee V, Shapiro S, Kennedy JL et al (2004). Association of the serotonin transporter and 5HT1Dbeta receptor genes with extreme, persistent and pervasive aggressive behaviour in children. Psychiatr Genet 14: 143-146.

Davis S, Vanhoutte P, Pages C, Caboche J, Laroche S (2000). The MAPK/ERK cascade targets both Elk-1 and cAMP response element-binding protein to control long-term potentiationdependent gene expression in the dentate gyrus in vivo. J Neurosci 20: 4563-4572.

Della Rocca GJ, Mukhin YV, Garnovskaya MN, Daaka Y, Clark GJ, Luttrell LM et al (1999). Serotonin 5-HT1A receptor-mediated 
Erk activation requires calcium/calmodulin-dependent receptor endocytosis. J Biol Chem 274: 4749-4753.

Dwivedi Y, Rizavi HS, Roberts RC, Conley RC, Tamminga CA, Pandey GN (2001). Reduced activation and expression of ERK1/ 2 MAP kinase in the post-mortem brain of depressed suicide subjects. J Neurochem 77: 916-928.

Edwards DH, Kravitz EA (1997). Serotonin, social status and aggression. Curr Opin Neurobiol 7: 812-819.

Einat H, Manji HK, Gould TD, Du J, Chen G (2003a). Possible involvement of the ERK signaling cascade in bipolar disorder: behavioral leads from the study of mutant mice. Drug News Perspect 16: 453-463.

Einat H, Yuan P, Gould TD, Li J, Du J, Zhang L et al (2003b). The role of the extracellular signal-regulated kinase signaling pathway in mood modulation. J Neurosci 23: 7311-7316.

Ellinwood Jr EH (1971). Assault and homicide associated with amphetamine abuse. Am J Psychiatry 127: 1170-1175.

Feldker DE, Datson NA, Veenema AH, Meulmeester E, de Kloet ER, Vreugdenhil E (2003). Serial analysis of gene expression predicts structural differences in hippocampus of long attack latency and short attack latency mice. Eur J Neurosci 17: 379-387.

Ferris CF, Stolberg T, Delville Y (1999). Serotonin regulation of aggressive behavior in male golden hamsters (Mesocricetus auratus). Behav Neurosci 113: 804-815.

Freeman WM, Brebner K, Lynch WJ, Robertson DJ, Roberts DC, Vrana KE (2001a). Cocaine-responsive gene expression changes in rat hippocampus. Neuroscience 108: 371-380.

Freeman WM, Nader MA, Nader SH, Robertson DJ, Gioia L, Mitchell SM et al (2001b). Chronic cocaine-mediated changes in non-human primate nucleus accumbens gene expression. $J$ Neurochem 77: 542-549.

Glenn MB, Wroblewski B, Parziale J, Levine L, Whyte J, Rosenthal M (1989). Lithium carbonate for aggressive behavior or affective instability in ten brain-injured patients. Am J Phys Med Rehabil 68: 221-226.

Goetzl U, Grunberg F, Berkowitz B (1977). Lithium carbonate in the management of hyperactive aggressive behavior of the mentally retarded. Compr Psychiatry 18: 599-606.

Gold LH, Geyer MA, Koob GF (1989). Neurochemical mechanisms involved in behavioral effects of amphetamines and related designer drugs. NIDA Res Monogr 94: 101-126.

Golding A (1996). Violence and public health. J $R$ Soc Med 89: 501-505.

Grafman J, Schwab K, Warden D, Pridgen A, Brown HR, Salazar AM (1996). Frontal lobe injuries, violence, and aggression: a report of the Vietnam Head Injury Study. Neurology 46: 1231-1238.

Greengard P (2001). The neurobiology of slow synaptic transmission. Science 294: 1024-1030.

Hao Y, Creson T, Zhang L, Li P, Du F, Yuan P et al (2004). Mood stabilizer valproate promotes ERK pathway-dependent cortical neuronal growth and neurogenesis. J Neurosci 24: 6590-6599.

Hawks D, Mitcheson M, Ogborne A, Edwards G (1969). Abuse of methylamphetamine. Br Med J 1: 715-721.

Huber R, Orzeszyna M, Pokorny N, Kravitz EA (1997). Biogenic amines and aggression: experimental approaches in crustaceans. Brain Behav Evol 50(Suppl 1): 60-68.

Johansson AK, Hansen S (2000). Increased alcohol intake and behavioral disinhibition in rats with ventral striatal neuron loss. Physiol Behav 70: 453-463.

Jones DH, Martin H, Madrazo J, Robinson KA, Nielsen P, Roseboom PH et al (1995). Expression and structural analysis of 14-3-3 proteins. J Mol Biol 245: 375-384.

Korte SM, Meijer OC, de Kloet ER, Buwalda B, Keijser J, Sluyter F et al (1996). Enhanced 5-HT1A receptor expression in forebrain regions of aggressive house mice. Brain Res 736: 338-343.
Kramer JC, Fischman VS, Littlefield DC (1967). Amphetamine abuse. Pattern and effects of high doses taken intravenously. JAMA 201: 305-309.

Kuikka JT, Tiihonen J, Bergstrom KA, Karhu J, Rasanen P, Eronen M (1998). Abnormal structure of human striatal dopamine reuptake sites in habitually violent alcoholic offenders: a fractal analysis. Neurosci Lett 253: 195-197.

Lederhendler II (2003). Aggression and violence: perspectives on integrating animal and human research approaches. Horm Behav 44: 156-160.

London ED, Simon SL, Berman SM, Mandelkern MA, Lichtman $\mathrm{AM}$, Bramen $\mathrm{J}$ et al (2004). Mood disturbances and regional cerebral metabolic abnormalities in recently abstinent methamphetamine abusers. Arch Gen Psychiatry 61: 73-84.

Maeda H, Sato T, Maki S (1985). Effects of dopamine agonists on hypothalamic defensive attack in cats. Physiol Behav 35: 89-92.

Malone RP, Luebbert J, Pena-Ariet M, Biesecker K, Delaney MA (1994). The Overt Aggression Scale in a study of lithium in aggressive conduct disorder. Psychopharmacol Bull 30: 215-218.

Manji HK, Chen G (2002). PKC, MAP kinases and the bcl-2 family of proteins as long-term targets for mood stabilizers. Mol Psychiatry 7(Suppl 1): S46-S56.

Manji HK, Lenox RH (1999). Ziskind-Somerfeld Research Award. Protein kinase $\mathrm{C}$ signaling in the brain: molecular transduction of mood stabilization in the treatment of manic-depressive illness. Biol Psychiatry 46: 1328-1351.

Manuck SB, Flory JD, Muldoon MF, Ferrell RE (2002). Central nervous system serotonergic responsivity and aggressive disposition in men. Physiol Behav 77: 705-709.

McDougle CJ, Stigler KA, Posey DJ (2003). Treatment of aggression in children and adolescents with autism and conduct disorder. J Clin Psychiatry 64(Suppl 4): 16-25.

Miczek KA, Maxson SC, Fish EW, Faccidomo S (2001). Aggressive behavioral phenotypes in mice. Behav Brain Res 125: 167-181.

Miczek KA, O'Donnell JM (1978). Intruder-evoked aggression in isolated and nonisolated mice: effects of psychomotor stimulants and L-dopa. Psychopharmacology (Berlin) 57: 47-55.

Miczek KA, Tidey JW (1989). Amphetamines: aggressive and social behavior. NIDA Res Monogr 94: 68-100.

Mizoguchi H, Yamada K, Mizuno M, Mizuno T, Nitta A, Noda Y et al (2004). Regulations of methamphetamine reward by extracellular signal-regulated kinase $1 / 2$ /ets-like gene- 1 signaling pathway via the activation of dopamine receptors. $\mathrm{Mol}$ Pharmacol 65: 1293-1301.

Olivier B, Mos J, van Oorschot R, Hen R (1995). Serotonin receptors and animal models of aggressive behavior. Pharmacopsychiatry 28(Suppl 2): 80-90.

Platt JE, Campbell M, Cohen IL (1981). Effects of lithium carbonate and haloperidol on cognition in aggressive, hospitalized school age children (proceedings). Psychopharmacol Bull 17: 123-125.

Posternak MA, Zimmerman M (2002). Anger and aggression in psychiatric outpatients. J Clin Psychiatry 63: 665-672.

Prothrow-Stith DB (1995). The epidemic of youth violence in America: using public health prevention strategies to prevent violence. J Health Care Poor Underserved 6: 95-101.

Pucilowski O, Valzelli L (1986). Chemical lesions of the nucleus accumbens septi in rats: effects on muricide and apomorphineinduced aggression. Behav Brain Res 19: 171-178.

Schiff HB, Sabin TD, Geller A, Alexander L, Mark V (1982). Lithium in aggressive behavior. Am J Psychiatry 139: 1346-1348. Schultz W (2002). Getting formal with dopamine and reward. Neuron 36: 241-263.

Sekine Y, Iyo M, Ouchi Y, Matsunaga T, Tsukada H, Okada $\mathrm{H}$ et al (2001). Methamphetamine-related psychiatric symptoms and reduced brain dopamine transporters studied with PET. Am J Psychiatry 158: 1206-1214.

Shader RI, Jackson AH, Dodes LM (1974). The antiaggressive effects of lithium in man. Psychopharmacologia 40: 17-24. 
METH, aggressiveness, and MAP kinase pathways BP Sokolov and JL Cadet

Sharma P, Veeranna, Sharma M, Amin ND, Sihag RK, Grant P et al (2002). Phosphorylation of MEK 1 by $\mathrm{cdk} 5 / \mathrm{p} 35$ down-regulates the mitogen-activated protein kinase pathway. J Biol Chem 277: 528-534.

Sheard MH (1975). Lithium in the treatment of aggression. J Nerv Ment Dis 160: 108-118.

Sheard MH (1984). Clinical pharmacology of aggressive behavior. Clin Neuropharmacol 7: 173-183.

Shintomi K (1975). Effects of psychotropic drugs on methamphetamine-induced behavioral excitation in grouped mice. Eur $J$ Pharmacol 31: 195-206.

Siegel A, Roeling TA, Gregg TR, Kruk MR (1999). Neuropharmacology of brain-stimulation-evoked aggression. Neurosci Biobehav Rev 23: 359-389.

Silva RR, Ernst M, Campbell M (1993). Lithium and conduct disorder. Encephale 19: 585-590.

Sokolov BP, Schindler CW, Cadet JL (2004). Chronic methamphetamine increases fighting in mice. Pharmacol Biochem Behav 77: 319-326.

Strakowski SM, Delbello MP, Adler CM (2005). The functional neuroanatomy of bipolar disorder: a review of neuroimaging findings. Mol Psychiatry 10: 105-116.
Swann AC (2003). Neuroreceptor mechanisms of aggression and its treatment. J Clin Psychiatry 64(Suppl 4): 26-35.

Swann AC, Dougherty DM, Pazzaglia PJ, Pham M, Moeller FG (2004). Impulsivity: a link between bipolar disorder and substance abuse. Bipolar Disord 6: 204-212.

Szuster RR (1990). Methamphetamine in psychiatric emergencies. Hawaii Med J 49: 389-391.

Valjent E, Corvol JC, Pages C, Besson MJ, Maldonado R, Caboche J (2000). Involvement of the extracellular signal-regulated kinase cascade for cocaine-rewarding properties. J Neurosci 20: 8701-8709.

Weller EB, Rowan A, Elia J, Weller RA (1999). Aggressive behavior in patients with attention-deficit/hyperactivity disorder, conduct disorder, and pervasive developmental disorders. J Clin Psychiatry 60(Suppl 15): 5-11.

Wroblewski BA, Joseph AB, Kupfer J, Kalliel K (1997). Effectiveness of valproic acid on destructive and aggressive behaviours in patients with acquired brain injury. Brain Inj 11: 37-47.

Yen CF, Ko CH, Yen JY, Liu SJ (2005). Areca quid chewing and methamphetamine use in Taiwanese adolescents. Public Health 119: $50-54$. 